\title{
An electron microscope study of a natural population of picoplankton from the Celtic Sea
}

\author{
I. R. Joint and R. K. Pipe \\ Natural Environment Research Council, Institute for Marine Environmental Research, Prospect Place, The Hoe, \\ Plymouth PL1 3DH, United Kingdom
}

\begin{abstract}
Water samples from the Celtic Sea have been concentrated and examined by scanning and transmission electron microscopy. Cyanobacteria were abundant and had maximum cell dimensions ranging from 0.5 to $1.0 \mu \mathrm{m}$. In addition to these prokaryotic cells, numerous eukaryotic algae were present which had maximum cell dimensions only slightly larger $(0.85$ to $2 \mu \mathrm{m})$ than the cyanobacteria; these eukaryotic cells were 'Chlorella-like' green algae, possessing neither scales nor flagella. Many of these eukaryotic algae and all of the cyanobacteria would pass through a $1 \mu \mathrm{m}$ pore-size sieve and were the organisms responsible for the high rates of primary production by picoplankton in the Celtic Sea.
\end{abstract}

\section{INTRODUCTION}

Several recent reports have emphasised the importance of very small phytoplankton in the sea. Many of these are based on size fractionation of primary productivity measurements (Gieskes et al., 1979; Larsson and Hagström, 1982; Joint and Pomroy, 1983; Li et al., 1983; Platt et al., 1983; Takahashi and Bienfang, 1983; Douglas, 1984) and demonstrate that between 20 and $80 \%$ of the total primary production was by organisms smaller than $1 \mu \mathrm{m}$ diameter; such phytoplankton are usually referred to as picoplankton. The word picoplankton was originally suggested by Sieburth et al. (1978) to describe organisms smaller than $2 \mu \mathrm{m}$ but many workers are adopting a practical definition of organisms which pass through a $1 \mu \mathrm{m}$ pore size filter.

In addition to the kinetic evidence for the importance of the very small phytoplankton, there have been a few studies that have attempted to identify the organisms responsible. Waterbury et. al. (1979) and Johnson and Sieburth (1979) demonstrated the occurrence of small unicellular cyanobacteria of the genus Synechococcus in a variety of regions including the Arabian Sea, the Pacific, the North Atlantic and North American estuaries. The characteristic orange fluorescence of small cyanobacteria has also been reported by Li et al. (1983) and Platt et al. (1983) and it is generally assumed that photoautotrophic production by cells $<1 \mu \mathrm{m}$ is due to cyanobacteria. However, Johnson and Sieburth (1982) have also reported the presence of very small eukaryotic algae in the North Atlantic; these cells would also pass through $1 \mu \mathrm{m}$ pore size filters and would contribute to the measured production of the picoplankton. It is clear that not all photosynthetic picoplankton is cyanobacteria.

We have previously shown (Joint and Pomroy, 1983) the quantitative importance of picoplankton and small nanoplankton to the production of the Celtic Sea. Using epifluorescence microscopy, we identified microflagellates as the major component of the nanoplankton but we had no evidence for which organisms were responsible for the production in the $<1 \mu \mathrm{m}$ size fraction. Attempts at transmission electron microscopy on samples from 1982 were unsuccessful but did indicate the presence of small eukaryotic algae. The purpose of this paper is to describe the results of an electron microscope study of the phytoplankton of the region which demonstrate the presence of both cyanobacteria and very small eukaryotic algae.

\section{METHODS}

The study area was located at Station CS2 $\left(50^{\circ} 30^{\prime} \mathrm{N}\right.$; $07^{\circ} 00^{\prime} \mathrm{W}$ ) in the Celtic Sea and has been described by Joint and Pomroy (1983). Water samples were taken with 71 National Institute of Oceanography water bottles from $10 \mathrm{~m}$ depth at $0630 \mathrm{~h}$ on 30 August 1983 and transferred to clean plastic containers; numbers of microflagellates were determined as previously 
described (Joint and Pomroy, 1983). The sample for electron microscopy was fixed by the addition of a mixture of $25 \%$ electron microscopy (EM) grade glutaraldehyde and formaldehyde prepared from EM grade paraformaldehyde, to a final concentration of $1 \%$ each aldehyde. The sample was stored in the cold for $10 \mathrm{~d}$ before being processed in the laboratory.

Samples were prepared for scanning electron microscopy (SEM) by gentle filtration of $20 \mathrm{ml}$ samples through $0.2 \mu \mathrm{m}$ pore-size Nuclepore membranes. Salt was removed by washing the filters with small amounts of deionised water and the filters were then dehydrated through a graded series of ethanol; the ethanol was replaced with 1,1,2-trichlorotrifluoroethane (Freon 113, Polaron Equipment Ltd.) in a graded series of ethanol-Freon mixtures to $100 \%$ Freon. The samples were dried in a critical point drier, mounted on stubs with double-sided sticky tape and vacuum coated with $100 \AA$ of gold. The samples were examined with a Jeol JSM-35C scanning electron microscope.

The samples for transmission electron microscopy (TEM) had to be prefiltered to remove some large cells which were so hard that they interfered with the successful sectioning with the ultramicrotome; even after these large cells were removed, difficulty was still experienced with sectioning. The sample was gently filtered through $8 \mu \mathrm{m}$ Nuclepore filters which were changed frequently to ensure that small particles were not trapped as the pores clogged. The effect of this prefractionation procedure was investigated by SEM and, apart from the removal of a small number of cells that were $>8 \mu \mathrm{m}$ diameter, there was no discernable difference in the $<8 \mu \mathrm{m}$ population of cells in the preand post-fractionated samples: we believe that this prefractionation step did not influence our observations on small phytoplankton using TEM.

After prefractionation, the sample was centrifuged in six $250 \mathrm{ml}$ polycarbonate bottles in a refrigerated centrifuge $\left(4^{\circ} \mathrm{C}\right)$ for $75 \mathrm{~min}$ at $12000 \times \mathrm{g}$; the same bottles were used to spin down the whole sample. No pellet was visible in these bottles but the presumed pellet was resuspended and centrifuged in a smaller volume in $15 \mathrm{ml}$ polycarbonate centrifuge tubes at $1400 \times \mathrm{g}$ for $60 \mathrm{~min}$ and finally in $0.5 \mathrm{ml}$ polyethylene tubes in a Beckman Microfuge for $15 \mathrm{~min}$; at this stage a pellet of about $1 \mathrm{~mm}$ diameter was visible. The pellet was surrounded with molten $\left(45^{\circ} \mathrm{C}\right)$ sterile agar which was quickly cooled and the solidified agar and pellet were removed by cutting away the polyethylene centrifuge tube. Excess agar was trimmed away and the samples were stored overnight in $3 \%$ glutaraldehyde in $0.1 \mathrm{~mol}$ $1^{-1}$ cacodylate buffer at $\mathrm{pH} 7.20$. The samples were then washed for $30 \mathrm{~min}$ in 2 changes of buffer and fixed for $2 \mathrm{~h}$ with $1 \%$ osmium tetroxide in buffer. After washing for $30 \mathrm{~min}$ in buffer, the samples were dehydrated in a graded ethanol series with 3 final changes of absolute ethanol and infiltrated overnight with LR white resin (London Resin Co Ltd). Polymerisation was carried out in gelatin capsules at $60^{\circ} \mathrm{C}$ for $24 \mathrm{~h}$. Silver to gold sections were cut on a Reichert Ultracut E ultramicrotome, collected on carbon coated grids and stained with uranyl acetate and lead citrate. The sections were examined in a Philips 300 electron microscope with an accelerating voltage of $60 \mathrm{kV}$.

\section{RESULTS}

\section{Comparability of samples taken in August 1982 and August 1983}

We had attempted to examine samples taken in 1982 by TEM but had been unsuccessful and the study was repeated in August 1983; but how comparable were the phytoplankton sampled in the $2 \mathrm{yr}$ when the weather conditions were quite different? On each cruise period in 1982 there were strong winds and very few days of sunshine; in contrast, there were long periods of sunshine throughout the summer of 1983 . This difference is reflected in the surface water temperatures measured at Station CS2 (Fig. 1). In August 1982 , the surface mixed layer was isothermal to a depth of $24 \mathrm{~m}$ with a temperature of $16.6^{\circ} \mathrm{C}_{i}$ in August 1983 , the surface water was much warmer $\left(19.5^{\circ} \mathrm{C}\right)$ with near surface warming to $21.2^{\circ} \mathrm{C}$.

The biomass of microflagellates present was used as a comparison between the $2 \mathrm{yr}$; the numbers of microflagellates were similar, albeit slightly lower in 1983 than in 1982 (Fig. 1). Primary production by picoplankton and small nanoplankton production were also very similar. In 1982, the proportion of carbon fixed in the

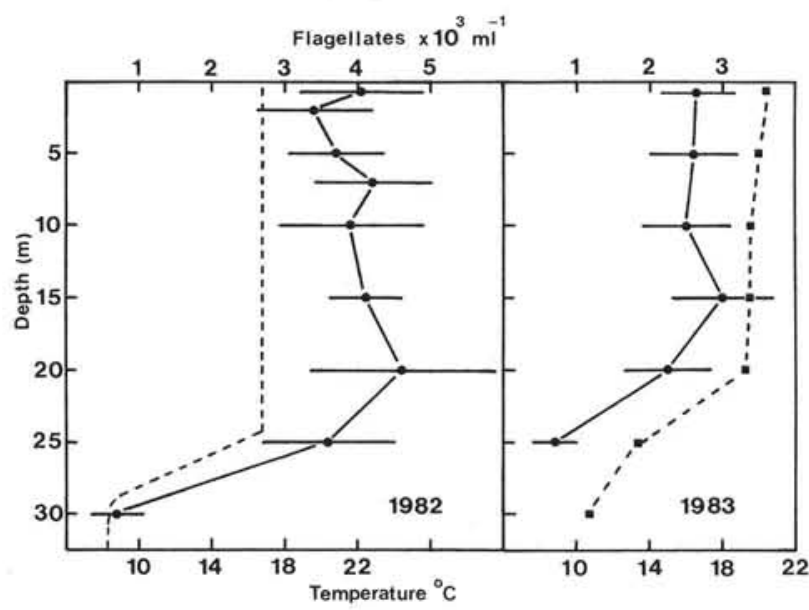

Fig. 1. Numbers of microflagellates $( \pm 2 \mathrm{SE})$ in surface waters at Station CS2 in August 1982 and August 1983 plotted with water temperature $(---)$ 
3 size fractions $>5 \mu \mathrm{m},<5 \mu \mathrm{m}$ to $1 \mu \mathrm{m}$, and $<1 \mu \mathrm{m}$ (but excluding dissolved organic carbon production) was ca. 25:40:35\% (Joint and Pomroy, 1983); in August 1983 the proportions (in slightly different size fractions, $>5 \mu \mathrm{m},<5 \mu \mathrm{m}$ to $>0.8 \mu \mathrm{m}$, and $<0.8 \mu \mathrm{m}$ ) were ca. 35:45:20\% (N. J. P. Owens, Institute for Marine Environmental Research, pers. comm.). Although production in the $>5 \mu \mathrm{m}$ size fraction was about $10 \%$ greater than in $1982,65 \%$ of the production in 1983 occurred in the $<5 \mu \mathrm{m}$ fraction and there was significant production by picoplankton. The phytoplankton demonstrated by TEM in this paper is presumably similar to that responsible for the picoplankton production in 1982 reported by Joint and Pomroy (1983).

\section{Scanning electron microscopy}

Scanning electron microscopy (SEM) is extremely useful in identifying phytoplankton such as diatoms which have distinct morphological features. However, SEM proved less useful in identifying the picoplankton present in the Celtic Sea. It was known (Joint and Pomroy, 1983) that the organisms $>1 \mu \mathrm{m}$ were mostly small flagellates which were assumed to be photosynthetic and responsible for the observed photoautotrophic production. SEM photographs (Fig. 2) show the structure of the small flagellates in more detail than was obtained using epifluorescence, but it is not possible to identify these cells as photosynthetic. Similarly, SEM cannot be used to identify phytoplankton of $1 \mu \mathrm{m}$ diameter or smaller. Many featureless cocci of ca. $1 \mu \mathrm{m}$ diameter can be seen in Fig. 2 as well as smaller cells $(<0.5 \mu \mathrm{m})$ which are presumably heterotrophic bacteria. Insufficient information was obtained using SEM to identify the organisms of interest, so the samples were examined by TEM.

\section{Transmission electron microscopy}

A large number of cells were examined and Fig. 3 shows some representative picoplankton from the Celtic Sea. Two eukaryotic cells with similar dimensions and structure are shown in Fig. 3a; Cell A has a width of $0.95 \mu \mathrm{m}$ and a length of $1.53 \mu \mathrm{m}$ and Cell B is $0.89 \mu \mathrm{m}$ wide and $1.47 \mu \mathrm{m}$ long. The size of structures in thin section depends on the section plane and may not represent the true size of the cell; however, the dimensions quoted here are consistent with the cells in the SEM micrographs and are probably close to actual cell dimensions. Each cell appears to have a single chloroplast and a dominant feature of each cell is the presence of a starch-like grain within the chloroplast. Several small (ca. 0.2 to $0.4 \mu \mathrm{m}$ ) heterotrophic bacteria (h) are also present. A slightly larger eukaryotic cell $(1.25 \times 1.59 \mu \mathrm{m})$ is shown in Fig. 3b. There appear to be 2 chloroplasts in this cell. This may be an artefact of the orientation of a single chloroplast which could have been sectioned at 2 places in the same plane; alternatively, the chloroplast may have divided just prior to cell divison. Also in Fig. 3b is a cell (c) with the typical ultrastructure of a cyanobacterium; this cell has dimensions of $0.47 \times 0.58 \mu \mathrm{m}$ and is larger than the heterotrophic bacteria in the sample. The size of the cyanobacteria was quite variable; Fig. 3c shows a cyanobacterium $0.47 \mu \mathrm{m}$ wide and $0.74 \mu \mathrm{m}$ long and Fig. 3d shows one of the largest cyanobacteria with cell dimensions of $0.94 \times 1.07 \mu \mathrm{m}$. In both cases, the distinctive peripheral arrangement of the thylakoid is clearly visible; the cell envelope appears to consist of several layers and most of the cells possess several polyhedral bodies, which are presumably carboxysomes.

A eukaryotic cell with the same dimensions as the cyanobacteria is shown in Fig. 3e. This cell is $0.86 \times$ $1.12 \mu \mathrm{m}$ with a distinct nucleus and chloroplast; the chloroplast appears to have 2 thylakoids per lamella which surround the starch-like grain. The periplast of these cells is less smooth and possesses more surface structure than the cells in Fig. 3a. Two thylakoids per lamella can be seen in a cell $1.37 \times 1.93 \mu \mathrm{m}$ (Fig. 3f) and in Fig. 3g, the same cell as Cell A in Fig. 3a at a higher magnification; both cells have a distinct starchlike grain.

Johnson and Sieburth (1982) showed an example of an aberrant cell form which they found in tropical waters. We have found occasional examples of similar cells; the large cell $(3.23 \times 4.31 \mu \mathrm{m})$ in Fig. $3 \mathrm{~h}$ has cytoplasm which appears to have shrunk away from the cell wall. Johnson and Sieburth suggested that such cells were senescent and deteriorating. However, it is also possible that this is a section through a colourless lorica-dwelling flagellate such as a Choanoflagellate or a flagellate of the genus Biocoeca (Moestrup and Thomsen, 1976) and does not indicate cell deterioration.

\section{DISCUSSION}

The SEM study confirmed our earlier fluorescence microscope observations (Joint and Pomroy, 1983), that the majority of cells $>2 \mu \mathrm{m}$ were flagellates; these were presumably photoautotrophic and responsible for most of the primary production measured in the $>1 \mu \mathrm{m}$ fraction. However, the identity of the smallest cells was only revealed by TEM which showed the presence of numerous cyanobacteria and small eukaryotic algae.

The ultrastructure of the cyanobacteria is consistent 



Fig. 2. Scanning electron micrographs of phytoplankton from CS2 in August 1983; the sample was filtered onto $0.2 \mu \mathrm{m}$ Nuclepore membranes and shows small flagellates ( 1 to $3 \mu \mathrm{m})$ and smaller cocci $(0.5$ to $1 \mu \mathrm{m})$. The smallest cells $(<0.5 \mu \mathrm{m})$ are presumed to be heterotrophic bacteria. Scale bars are $1 \mu \mathrm{m}$

with these cells belonging to the genus Synechococcus (Rippka et al., 1979), although positive identification must await isolation and characterisation of pure cultures. All the cyanobacteria observed in this study had a peripheral arrangement of thylakoids of the type described by Johnson and Sieburth (1979) as Type I: we did not observe any cells of the Type II or III described by these authors. All of the cyanobacteria were probably small enough to pass through a $1 \mu \mathrm{m}$ pore size sieve and would contribute to the primary production measured in the $<1 \mu \mathrm{m}$ fraction by Joint and Pomroy (1983).

However, many of the small eukaryotic algae would also pass through a $1 \mu \mathrm{m}$ pore-size sieve. Sieburth et al. (1978) stated that small particles line up longitudinally in the flow of liquid as it passes through Nuclepore membranes and so retention is a function of cell width and not length. Many of the small eukaryotic cells (Fig. 3) are $<1 \mu \mathrm{m}$ wide and probably would have contributed to the production in the $<1 \mu \mathrm{m}$ fraction. It is difficult to be quantitative but on the basis of the TEM study, the biomass of small eukaryotic cells in August 1983 was quite similar to that of the cyanobacteria.

Identification of the small eukaryotes is problematical because so little is known about these algae; they are small 'Chlorella-like' green algae but, as with the cyanobacteria, identification will depend on taxonomic studies of pure cultures. One small alga (1 to $1.5 \mu \mathrm{m})$ that has been reported in large numbers in both coastal and oceanic waters is Micromonas pusilla (Thondson, 1976); this alga was also found by Johnson and Sieburth (1982) and is readily recognised by the presence of a dark pyrenoid. None of the small cells examined in this study had a pyrenoid and $M$. pusilla was not a significant component of the picoplankton of the Celtic Sea in August.

It is not known if any of the cells in Fig. 3 had 

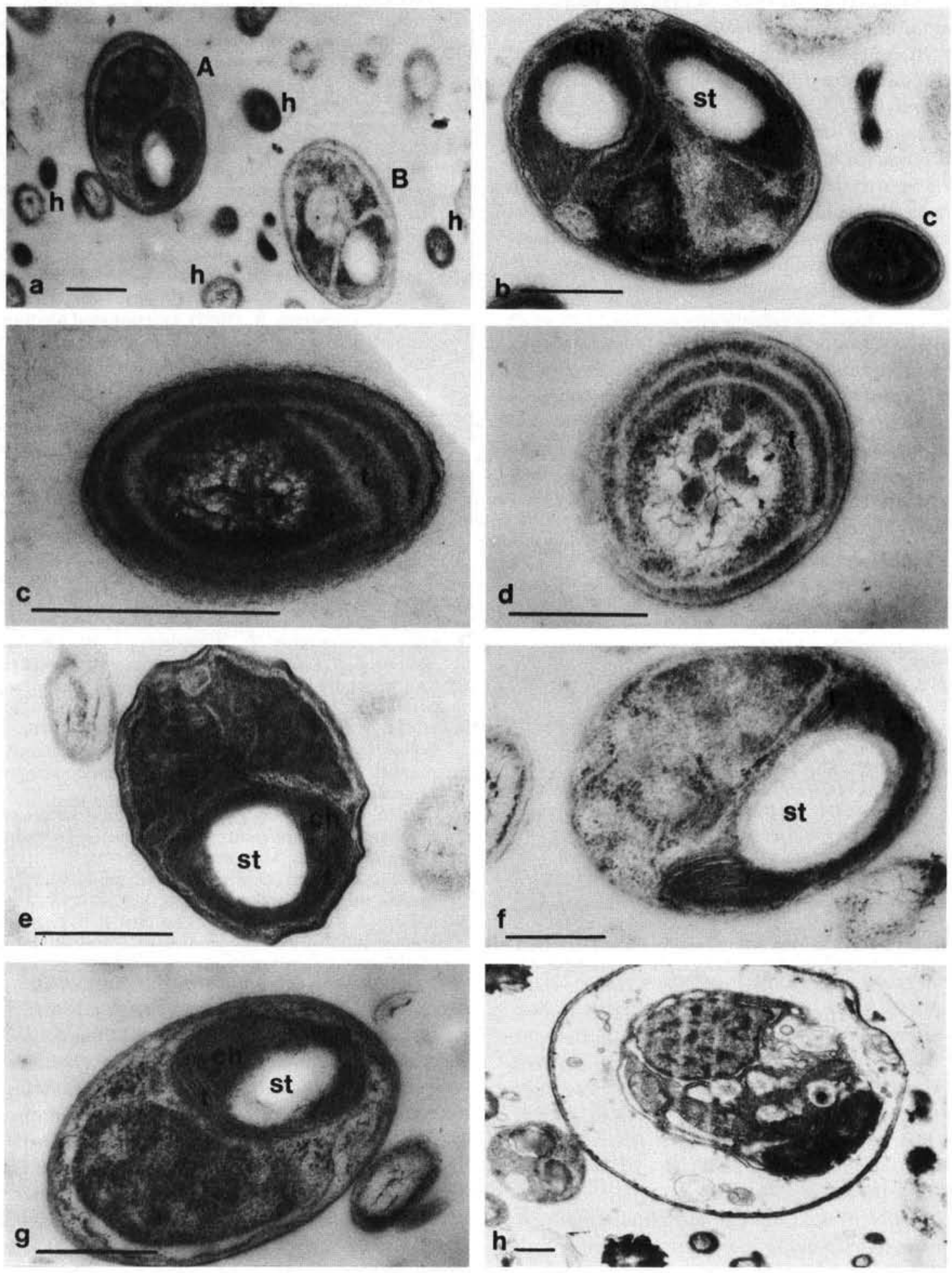

Fig. 3. Transmission electron micrographs of phytoplankton from the same sample as examined by SEM (Fig. 2) showing very small eukaryotic algae and cyanobacteria (c). h: heterotrophic bacteria $(0.2$ to $0.4 \mu \mathrm{m})$; ch: chloroplast; st: starch-like grain; t: thylakoid. Each scale bar is $0.5 \mu \mathrm{m}$ 
flagella; although many cells were examined, none of the sections coincided with the attachment point of a flagellum to the cell and this suggests that these cells were not flagellated. Similarly, none of the small eukaryotic cells possessed scales and were presumably not Prasinophytes.

One of the most striking morphological features of the small eukaryotic algae found in the Celtic Sea is the presence of starch as storage product. In order to utilize these phytoplankton efficiently any herbivore must possess the enzyme amylase. R. Williams (Institute for Marine Environmental Research) and J. F. Samain (Centre Océanologique de Bretagne, Brest, France; pers. comm.) have measured amylase and trypsin activity in Calanus helgolandicus stages V and VI (female) sampled in the Celtic Sea at the same time as the study of Joint and Pomroy (1983). Significant levels of amylase were found. Since we have not observed starch grains in sections of phytoplankton $>5 \mu \mathrm{m}$ to $<8 \mu \mathrm{m}$ diameter, this perhaps suggests that $C$. helgolandicus can feed directly on these very small algae which store starch. Further experimental work is required to show if macrozooplankton can feed directly on these small eukaryotic algae and cyanobacteria which are so important in the Celtic Sea.

Acknowledgements. We thank Dr. N. J. P. Owens for collecting the water samples and for his data on primary production in August 1983; Mr. A. J. Pomroy for the scanning electron micrographs; Dr. J. C. Green for very helpful discussion; the Director of the Marine Biological Association for use of the electron microscopes. This work forms part of the Near-shore Ecology programme of the Institute for Marine Environmental Research, a component of the UK Natural Environment Research Council.

\section{LITERATURE CITED}

Douglas, D. J. (1984). Microautoradiography-based enumeration of photosynthetic picoplankton with estimates of car- bon-specific growth rates. Mar. Ecol. Prog. Ser. 14: 223-228

Gieskes, W. W. C., Kraay, G. W., Baars, M. A. (1979). Current ${ }^{14} \mathrm{C}$ methods for measuring primary production: gross underestimates in oceanic waters. Neth. J. Sea Res. 13: 58-78

Johnson, P. W., Sieburth, J. McN. (1979). Chroococcoid cyanobacteria in the sea: a ubiquitous and diverse phototrophic biomass. Limnol. Oceanogr. 24: 928-935

Johnson, P. W., Sieburth, J. McN. (1982). In-situ morphology and occurrence of eucaryotic photoautotrophs of bacterial size in the picoplankton of estuarine and oceanic waters. J. Phycol. 18: 318-327

Joint, I. R., Pomroy, A. J. (1983). Production of picoplankton and small nanoplankton in the Celtic Sea. Mar. Biol. 77: 19-27

Larsson, U., Hagström, A. (1982). Fractionated phytoplankton primary production, exudate release and bacterial production in a Baltic eutrophication gradient. Mar. Biol. 67: $57-70$

Li, W. K. W., Subba Rao, D. V., Harrison, W. G., Smith, J. C., Cullen, J. J., Irwin, B., Platt, T. (1983). Autotrophic picoplankton in the tropical ocean. Science, N. Y. 219: 292-295

Moestrup, Ø., Thomsen, H. A. (1976). Fine structural studies on the flagellate genus Bicoeca: 1. Bicoeca maris with particular emphasis on the flagellar apparatus. Protistologica 7: 101-120

Platt, T., Subba Rao, D. V., Irwin, B. (1983). Photosynthesis of picoplankton in the oligotrophic ocean. Nature, Lond. 301: 702-704

Rippka, R., Deruelles, T., Waterbury, J. B., Herdman, M., Stanier, R. Y. (1979). Generic assignments, strain histories and properties of pure cultures of cyanobacteria. J. gen. Microbiol. 111: 1-61

Sieburth, J. McN., Smetacek, J., Lenz, J. (1978). Pelagic ecosystem structure: heterotrophic compartments of the plankton and their relationship to plankton size fractions. Limnol. Oceanogr. 23: 1256-1263

Takahashi, M., Bienfang, P. K. (1983). Size structure of phytoplankton biomass and photosynthesis in subtropical Hawaiian waters. Mar. Biol. 76: 203-211

Throndsen, J. (1976). Occurrence and productivity of small marine flagellates. Norw. J. Bot. 23: 269-293

Waterbury, J. B., Watson, S. W., Guillard, R. R. L., Brand, L. E. (1979). Widespread occurrence of a unicellular marine planktonic cyanobacterium. Nature, Lond. 277: 293-294 